\title{
En busca de la escritura perdida: los manuscritos de El libro vacío de Josefina Vicens
}

\section{In Search of the Lost Writing: the Manuscripts of El libro vacío by Josefina Vicens}

\author{
Emiliano Mastache* \\ Universidad Nacional Autónoma de México \\ Instituto de Investigaciones Filológicas \\ emiliano_mastache@yahoo.com
}

\section{RESUMEN}

El presente artículo cuenta con la honra de dar a conocer, por primera vez, en el ámbito de la literatura mexicana, un material de extraordinaria relevancia que ha permanecido inédito hasta este momento. Me refiero a los manuscritos de $E l$ libro vacio, primera novela de Josefina Vicens, publicada en 1958. No es necesario reiterar la importancia que dicha novela tiene y ha tenido desde su aparición hasta la actualidad. Se comprenderá, entonces, la trascendencia que supone el mostrar un material semejante. No obstante, es preciso advertir que el presente trabajo tiene como objeto fundamental analizar únicamente algunos de los aspectos más sobresalientes de los manuscritos, no sólo por las limitantes propias de este espacio, sino, en especial, por la vasta complejidad que poseen. Ésta constituye, pues, una primera aproximación a los manuscritos de El libro vacío. En el futuro se procurará dar a conocer otros notables aspectos de dicho material.

\section{Palabras clave}

Josefina Vicens, El libro vacío, manuscritos, procesos de creación, crítica genética.

\section{ABSTRACT}

This editorial has the privilege of being the first to disclose in the Mexican Literature scene, a material of extraordinary importance that has remained unpublished. I'm talking about the manuscripts of El libro vacio, the first novel of Josefina Vicens published in 1958. ${ }^{1}$ There's no need to stress the importance that such novel has had since its publication until now. In a similar mood, it's to be understood the transcendence that making public such material would imply. Nevertheless, the pur-

* unAm, Becario del Programa de Becas Posdoctorales en la UNAM, Instituto de Investigaciones Filológicas. Asesorado por la Dra. Ana Laura Zavala Díaz.

${ }^{1}$ There is a translation of the novel made by David Lauer, published in 1992. 


\section{Emiliano Mastache}

pose of this article is to analyze only some of the preeminent aspects of the manuscript, not just because of the restrictions proper of this space but also primarily because of the vast complexity that the manuscript possess. This is a first approach to the manuscripts of El libro vacio. In the future is intended to present other remarkable aspects of the material.

\section{KEYWORDS}

Josefina Vicens, El libro vacío, manuscripts, creation processes, genetic criticism.

RECEPCIÓN: 22/11/2019

ACEPTACIÓN: 24/01/2020

La proliferación de las tachaduras es sin duda como la vuelta de la conciencia a su existencia sensible, el retorno de lo sensible a su esencia de sensible, a su esencia estética.

$* * * *$

Sólo que, en esas bifurcaciones o tachaduras, se trata menos de recorrer los nuevos caminos que se abren, o de aferrarse al sentido corregido, que de captar el pensamiento en el momento privilegiado en el que se convierte en otra cosa que sí mismo.

Emmanuel Lévinas

La sensación no se realiza en el material sin que el material se traslade por completo a la sensación, al percepto o al afecto. Toda la materia se vuelve expresiva.

Deleuze y Guattari

\section{Los manuscritos de El libro vacío}

$\mathrm{E}$ l azar o, tal vez, una casualidad han determinado que los manuscritos de El libro dvacío curiosamente se constituyan, también, por dos cuadernos.

Por supuesto, de inmediato se piensa en una posible trasposición entre el proceso de creación emprendido por Josefina Vicens y el drama de José García, dado que en ambos casos se trata de dos cuadernos. Es decir, surge la tentación de suponer que la autora replicó, en la ficción, esa figura. No obstante, por una parte, no hay razones definitivas para sostener que Josefina Vicens sólo utilizó dos; como se verá, pudo haber otros, además de versiones mecanuscritas — un paso, este último, que justo José García no logra concretar- Y, por la otra, es importante destacar que, en los manuscritos de la novela, José García ya tiene perfectamente asumida la doble existencia de un cuaderno en el que sólo cosecha "fracasos" y de otro que permanecerá, de manera irremediable, en blanco. En una palabra, los dos cuadernos de José García, en tanto 
idea, preexistieron a los dos cuadernos manuscritos de Josefina Vicens. Cuestión que retomaré a lo largo de este trabajo.

No se trata, entonces, tal y como sucede en el texto publicado en 1958, de un cuaderno lleno de tentativas y otro vacío; ni, evidentemente, de dos cuadernos vacíos, pues imaginar un cuaderno en blanco que fuese parte de los "manuscritos" sería llevar al extremo el drama de José García, y pensar no en uno, sino en dos cuadernos vacíos como "los manuscritos" de la novela sería ensoñación o franco delirio. Por el contrario, se trata de dos cuadernos a cabalidad llenos. Ambos se encuentran poblados por trechos, párrafos y líneas escritos a mano; además de tachaduras diversas, correcciones y algunas glosas hechas por Josefina Vicens.

No me detendré mayormente en la descripción sino para decir que ambos son de igual tamaño, de forma francesa, rayados, cosidos y con pastas duras. La principal distinción es que el primero, fechado en 1954, se caracteriza por tener, en las pastas, motivos de color azul, y el otro, fechado en 1958, motivos, también en las pastas, de color rojo. En lo sucesivo y para diferenciarlos, me referiré a ellos por su color.

En términos generales, lo primero a destacar es que, tal parece, Josefina Vicens tenía una predilección por escribir en cuadernos. Todo indica que procuraba mantenerse dentro de los límites de dicho soporte. ${ }^{2}$ Ese gusto y hábito se esclarecen al reparar en que la autora no dejaba grandes espacios en blanco entre un "periodo" o "movimiento" de escritura y otro; simplemente, continuaba escribiendo, en la hoja siguiente, un nuevo tema o una nueva sección. En algunos casos, ese nuevo periodo es en suma claro no sólo porque aborda otro tema, sino también porque hay una modificación notable en los aspectos materiales de la escritura, como la caligrafía, el color de

${ }^{2}$ En el material consultado no hay una sola hoja suelta con anotaciones o con alguna adenda. Esto es de suma relevancia si se lo piensa en perspectiva comparada, por ejemplo, con el archivo de una escritora como la brasileña Clarice Lispector, quien, en contraste, cuenta literalmente con centenas de papeles sueltos, cheques, recibos o sobres escritos y sobreescritos, por anverso y reverso, con temas dispares, frases inquietantes y con tintas diversas. Al respecto, en breve publicaré un trabajo sobre el manuscrito de La hora de la estrella, en el que analizo el proceso de creación de la novela y, en particular, la forma en que ciertas notas hechas por la autora en trozos de papel y hojas sueltas se constituyeron en una pieza clave de dicho proceso. En sintonía, si Josefina Vicens tenía el hábito de usar hojas o pedazos de papel para escribir, de manera repentina, alguna frase o idea para después utilizarla o incorporarla en una versión más extensa, por desagracia no han quedado muestras de ello. Cabe plantear, entonces, que fue precisamente en los cuadernos que tuvo lugar una escritura seminal o primera, a partir de la cual la autora trabajó con posterioridad en diversas versiones (una pequeña nota en uno de los cuadernos sugiere que, después de ese primer esbozo a mano, recurrió a la máquina de escribir). Lamentablemente, no es posible ir más allá de esta suposición porque no hay modo de saber si Josefina Vicens trabajó varias versiones a mano, ni cuántas fueron, ni cuántas realizó a máquina hasta llegar al mecanuscrito que entregó, de forma definitiva, a la Compañía General de Ediciones S. A. - editorial que publicó por primera vez El libro vacío en 1958. 


\section{Emiliano Mastache}

la tinta y/o el espesor del trazo de la pluma. ${ }^{3}$ De cierta forma, en ese gesto de no dejar grandes trechos o incluso hojas enteras en blanco, entre los periodos de escritura, se percibe una preocupación por la continuidad del trabajo escritural; es decir, permite vislumbrar una constancia y un celo respecto a la propia escritura y su seguimiento atento, por parte de Josefina Vicens, en sus cuadernos.

Ahora bien, lo anterior debe ser matizado, porque la ganadora del Premio Xavier Villaurrutia procuraba escribir sólo en la página del lado derecho del cuaderno y dejaba completamente en blanco la página del lado izquierdo. Una imagen contrastante y que se repite en la mayoría de las hojas de los dos cuadernos: la página del lado izquierdo en blanco y el lado derecho saturado de letras, palabras, tachaduras y correcciones, es decir, lleno.

La razón para un uso tan diferenciado de las páginas no es definitiva, porque en el cuaderno azul sólo en dos casos hay alguna marca escrita del lado izquierdo. En contraste, en el cuaderno rojo, fechado varios años después, las páginas de ese lado en las que realizó alguna "intervención" son más de veinte, lo cual significa que el uso del lado izquierdo, de cierta forma, fue progresivo entre uno y otro cuaderno. De modo que cabe especular que esas hojas que quedaban en blanco se convirtieron, de manera paulatina, en otro espacio de escritura, utilizado en un segundo momento por Josefina Vicens con fines de revisión, corrección, comentario y reescritura.

Esto puede parecer una minucia, sin embargo, revela un proceder más o menos inesperado en la práctica escritural de la autora respecto a su primera novela, dado que resulta, hasta cierto punto, esquemático, en la medida en que establece un marcado contraste con la supuesta espontaneidad que, en teoría, le sería inherente tanto a la escritura ficticia y pretendidamente fallida de José García como a la propia escritura creadora y real de Josefina Vicens.

${ }^{3}$ El concepto de "movimiento o periodo de escritura" que aquí empleo se debe, en gran medida, al texto fundamental de Claudia Amigo Pino y Roberto Zular: Escrever sobre escrever. Uma introdução crítica à crítica genética. Los autores exponen: "De esa forma, la crítica genética surgida al interior de la crisis del estructuralismo verá los manuscritos de manera muy diferente de la filología. Mientras ésta los ve como referencia para la lectura de un texto original, para la crítica genética son portadores de un movimiento que puede ser considerado el proceso de creación literaria. Para comprender ese movimiento, no basta descubrir y presentar las variantes ante el lector en una edición crítica, sino encontrar otra estructuración móvil, aplicable a la creación. La nueva disciplina entonces trabajará con un objeto nuevo que escapa a las estructuras (los manuscritos como portadores de un movimiento), a partir de una mirada estructuralista (ya que propone elaborar una estructura de ese movimiento)" (17-18; la traducción es mía). Así, el concepto de "movimiento de escritura" o "periodo de escritura" lo utilizo para distinguir y señalar un tramo que posee unidad no sólo temática, sino también en relación con la caligrafía y los materiales, en especial el tipo de pluma o lápiz y, sobre todo, el color de la tinta; además, claro, de los espacios que la autora dejaba entre esos periodos. 
En todo caso, no se debe omitir lo obvio: es posible que el dejar en blanco las páginas del lado izquierdo, en ambos cuadernos, no haya obedecido a una necesidad inherente al proceso de escritura de Josefina Vicens - de manera que, con premeditación, dejase esos espacios para eventuales anotaciones y correcciones posteriores-, sino que bien puede deberse a una razón mucho más simple y, sin duda, menos inquietante: el hecho de que el papel pudiera dejar traslucir la escritura del reverso de la página imposibilitando la lectura de ambos lados o, incluso, humedeciendo la superficie con la tinta de la pluma - tipo fuente-, a tal grado que el papel terminara por afectarse o hasta rasgarse. ${ }^{4}$

Por último, en cuanto a los aspectos materiales, es necesario señalar que hay una excepción: buena parte de las páginas, en ambos cuadernos, aparecen escritas con lápiz y no con pluma, con lo cual la hipótesis sobre las condiciones del papel, recién expuesta, puede considerarse parcial, aunque no por ello se debe descartar, aun tratándose de escritura con lápiz. ${ }^{5}$

Hasta aquí los aspectos generales más relevantes.

\section{Dos anotaciones/dedicatorias}

A continuación, destacaré un aspecto un tanto desconcertante en ambos cuadernos y que es en suma atípico al tratarse de manuscritos de una obra literaria. Me refiero a una anotación inicial o "de apertura" que se encuentra en la parte interior de cada portada; es decir, en la cara interna de ésta (o lo que se acostumbra llamar, respecto a un libro, "segunda de forros"). En los dos cuadernos, las anotaciones resultan de enorme interés. ${ }^{6}$

${ }^{4}$ Lo ideal sería poder hacer pruebas con el papel de ambos cuadernos. Dado que eso es absolutamente inviable, cabe la posibilidad de buscar muestras de papel similares, del mismo grosor y tipo, y verificar con plumas diversas si se trasmina la tinta o no y si el papel sufre alteraciones de importancia.

${ }^{5}$ En este último caso, la cuestión radica en que el lápiz puede dejar marcas y surcos tales que dificultan escribir por el reverso de la hoja.

${ }^{6}$ En el presente trabajo se incluyen imágenes de las dos anotaciones y de dos pasajes originales de los manuscritos de El libro vacío, que constituyen el objeto central de análisis. No puedo dejar de agradecer infinita y entrañablemente a Aline Pettersson su autorización para publicar aquí imágenes parciales de pasajes manuscritos de El libro vacío. Más allá, es importante mencionar que, para cada una de las imágenes, ofrezco una transcripción lo más fiel posible al original $-\mathrm{O}$, como se acostumbra denominar: una transcripción paleográfica- Agradezco a los lectores su consideración, dado que la transcripción se hizo exclusivamente con las herramientas del procesador de textos electrónico en el que se redactó este artículo. Invito a que sean apreciados los diversos detalles que la misma supone, confrontándolos siempre con la imagen correspondiente. Sin duda, las reproducciones que aquí se muestran y analizan por 


\section{Emiliano Mastache}

En el caso del primero — el azul—, la nota dice lo siguiente:

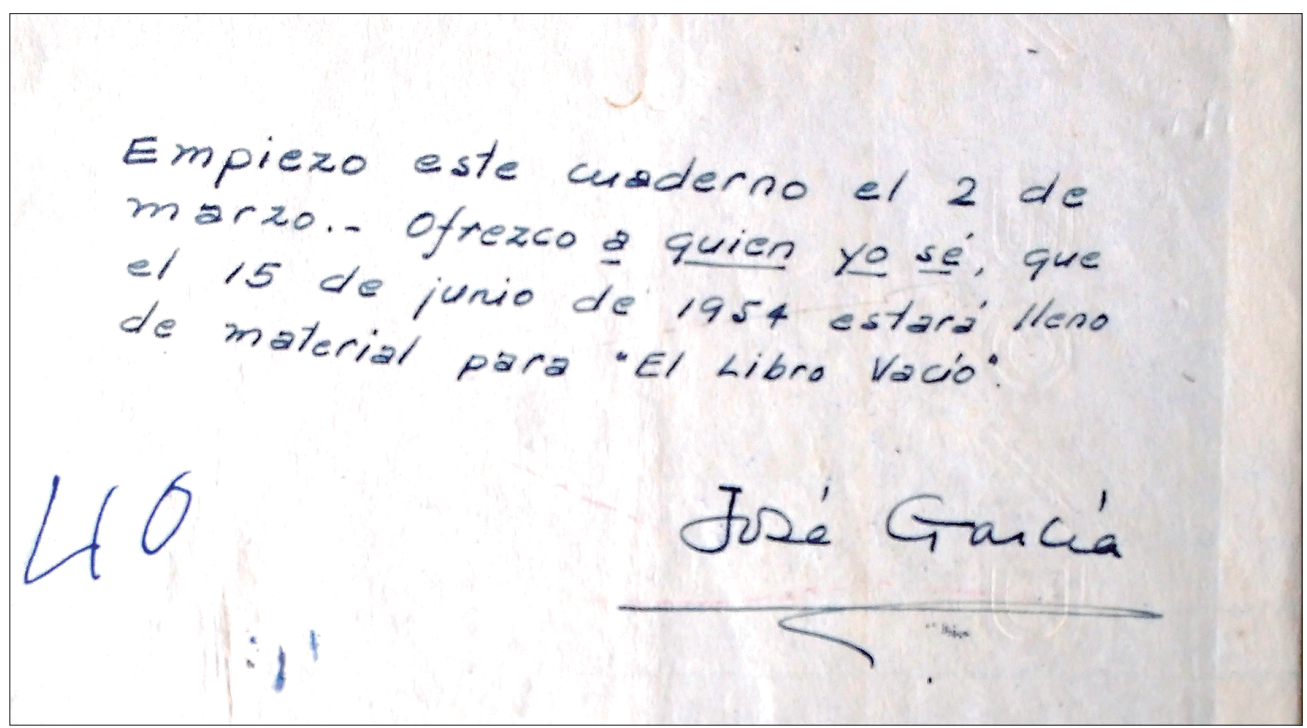

Imagen 1. Anotación en la cara interna de la portada. Cuaderno Azul

Empiezo este cuaderno el 2 de

marzo.- Ofrezco a quien yo sé, que

el 15 de junio de 1954 estará lleno

de material para "El Libro Vacío".

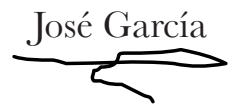

Como puede apreciarse, de inmediato llaman la atención algunas cuestiones, por ejemplo: las fechas (el plazo que se fija quien suscribió la nota es de dos meses y medio); o el que la persona a quien se ofrece el trabajo permanezca en el anonimato por decisión de quien escribe (nótese el subrayado que da un fuerte halo de misterio a la frase "a quien yo sé"), y, por último, un gesto inusitado para el caso de un manuscrito literario: el hecho de que la anotación constituya una especie de dedicatoria. ¿Por qué ese lapso de poco más de dos meses y no otro? ¿Se cumplió ese plazo o no? ¿Por qué no se dice el nombre de la persona a quien se "ofrece" el trabajo? ¿Se trata de una persona real o es alguien ficticio? ¿Esa especie de dedicatoria, entonces, se debe considerar como parte de la tentativa del protagonista, es decir, ya forma parte de la ficción?

primera vez constituyen un material sin parangón, en relación con la obra de una extraordinaria escritora como Josefina Vicens. Es mi anhelo que los lectores encuentren en él un motivo de reflexión enriquecedor y diverso. 
En todo caso, más allá de estos aspectos, posee mucha mayor trascendencia algo que, por su aparente obviedad, puede pasar desapercibido, y es el hecho simple y llano de que se mencionan, en el justo comienzo del cuaderno, tanto el título de la novela finalmente impresa (adviértase el uso de mayúsculas: "El Libro Vacío") como el nombre del protagonista, lo cual, como se verá, representa un flagrante contrasentido. Por lo demás, nótese que el propósito declarado es que, para el mes de junio, el cuaderno esté, precisamente, lleno.

La relevancia de esos tres detalles radica en que constituyen una contradicción con el drama de José García y su imposibilidad de escribir. O para decirlo de otro modo, se hace patente una tensión entre el mundo de José García, que se pretende intempestivo, fallido, imposible y, en fin, "vacío", y el ejercicio de creación llevado a cabo por Josefina Vicens para escribir su obra, que consistirá, paradójicamente, en "llenar el vacío".

De tal forma, si Vicens comenzó a escribir su novela contando, de antemano, con el nombre tanto del libro como del personaje principal, entonces, es preciso decirlo: el libro jamás estuvo ni ha estado realmente vacío - como sí lo están, según José García, sus cuadernos - La anotación, por consiguiente, evidencia que El libro vacío se encuentra en permanente contradicción: por un lado, buscando cumplir su propio nombre; por el otro, no obstante, hacer eso significará vaciar el libro, es decir, el libro posible que - en evocación a Blanchot - permanecerá como un libro siempre por venir.

Así, en la medida en que la autora consigue dar forma a su novela, su personaje permanecerá atrapado en la imposibilidad de escribir. Esto es: la imposibilidad de uno alimenta, inherentemente, la posibilidad de la otra y viceversa - un movimiento de la escritura que en sus más hondas raíces no es del todo discernible, pero que se deja pensar bajo la forma de una bifurcación- - ${ }^{7}$ En consecuencia, la impresión de una escritura intempestiva necesariamente se tambalea, pero, al mismo tiempo, se hace manifiesto el gran mérito de Josefina Vicens al haber logrado tal efecto de espontaneidad respecto a la escritura de José García. Con gran tino, Juan Villoro recuerda: “ningún artificio supera al de la 'espontaneidad' literaria” (8).

${ }^{7}$ Ciertas palabras de Emanuel Lévinas me permiten concebir, bajo esa forma, el juego progresivo de la doble autoría y la doble escritura que se da, en la novela y en los manuscritos, entre José García y Josefina Vicens: "En toda la última parte de su obra, Michel Leiris nos entrega el procedimiento de su arte: bifurcaciones (bifurs) o tachaduras (biffures) que dan título al libro y prestan también un sentido a esta sorprendente rehabilitación de la asociación de ideas. Bifurcaciones - porque las sensaciones, las palabras, los recuerdos, invitan al pensamiento a separarse, en cada instante, de la dirección que parece haber tomado y a caminar por senderos inesperados; tachaduras - porque el sentido unívoco de estos elementos es, a cada instante, corregido, sobrecargado" (158). 


\section{Emiliano Mastache}

Más allá, no puede obviarse: concebir la tentativa escritural de Josefina Vicens, en El libro vacio, en términos de "cumplir el propio nombre", abre la posibilidad de pensar la escritura también en términos de identidad; esto es, en relación no ya con el personaje José García, sino con la propia Josefina Vicens: cumplir su propio nombre. ${ }^{8}$

En síntesis, la breve anotación/dedicatoria que aparece en el cuaderno azul hace patente que hay una imbricación compleja entre vaciar el libro y cumplir el propio nombre (el título: "El Libro Vacío"). Y permítase el juego: también entre librar el vacío - librarlo/liberarlo haciéndolo libro - y cumplir el nombre propio.

Por último, es oportuno destacar que la anotación, como se habrá advertido, inevitablemente entraña una posible confusión en relación con la autoría: está firmada por José García, pero, a la vez, ya asigna un título a lo que escribirá en ese cuaderno, lo cual representa una contradicción evidente, dado que, no sobra decirlo con claridad: José García no podría tener noción de lo que está por empezar a escribir ni, mucho menos, podría contar, de antemano, con un título posible, porque eso no sólo le proporcionaría un mínimo rumbo, el cual no posee, sino que dejaría sin sustento su supuesto no saber escribir.

Dicho empalme es de enorme trascendencia, porque permite ver que, en efecto, la escritura del protagonista no constituyó en su origen algo ajeno a la propia escritura de Josefina Vicens. En ese sentido, resulta necesario señalar: será a partir del acto mismo de escribir - y esto se percibe progresivamente a lo largo de los manuscritos- que ambas escrituras, de manera paradójica, como un jardín de senderos que se bifurcan, terminarán por diferenciarse una de la otra para que la novela sea posible, aunque, ciertamente, sin dejar de ser una y la misma.

Si lo hasta aquí expuesto no es bastante desconcertante y, a la vez, enriquecedor, la anotación que aparece en el otro cuaderno - el rojo-, también al interior de la portada, termina por desajustar o desbalancear los encuadres posibles que, a partir de la lectura del texto impreso, germinan de modo natural. La anotación dice lo siguiente:

\footnotetext{
${ }^{8}$ No me refiero necesaria o exactamente a una interpretación en términos autobiográficos, a la que Josefina Vicens, de manera tajante, se opuso - véase la entrevista que le realizaron Daniel González Dueñas y Alejandro Toledo-. Empero, no es posible omitir que, a lo largo de ambos cuadernos manuscritos, existen aspectos que remiten implícita e inevitablemente a la autora, empezando por la obvia homonimia parcial entre su nombre (Josefina) y el de su personaje (José). Por lo demás, es importante subrayar la relevancia que tienen, en los cuadernos manuscritos, motivos como el cuerpo y la carne en relación con la escritura y con el propio proceso de creación de la novela, a manos, precisamente, de Josefina Vicens.
} 


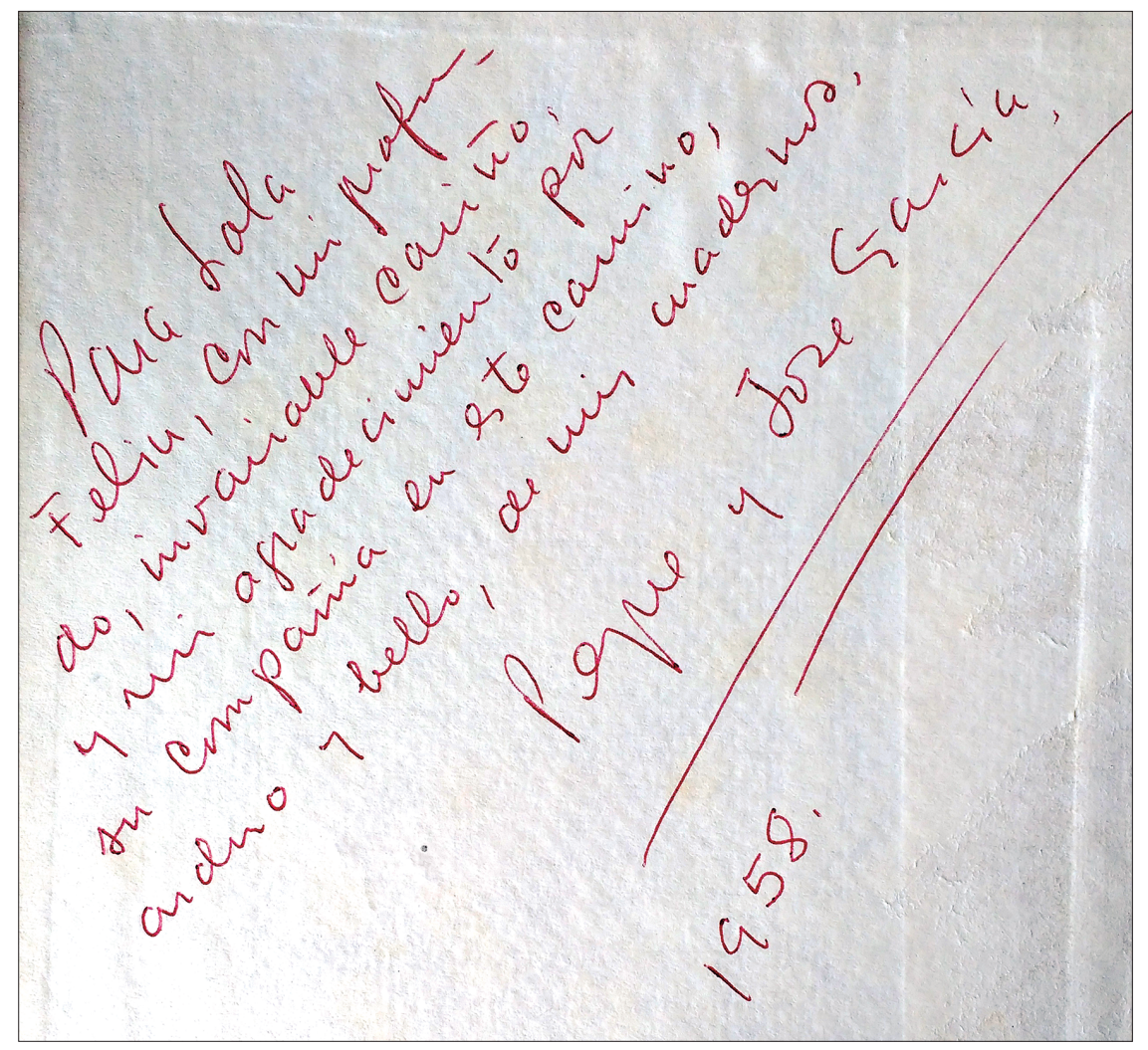

Imagen 2. Anotación en la cara interna de la portada. Cuaderno Rojo

Para Lola

Feliu, con mi profun-

do, invariable cariño,

y mi agradecimiento por

su compañía en este camino,

arduo y bello, de mis cuadernos,

\section{Peque y José García}

1958. ${ }^{9}$

${ }^{9}$ El nombre completo es Dolores P. Feliú, a quien se menciona en el libro de Jesús Ibarra: Los Bracho. Tres generaciones del cine mexicano, donde aparece compartiendo la autoría del guion de la película La rival con Josefina Vicens. No acentúo el apellido en la transcripción porque así aparece en el original. Más allá, el hecho de que en este segundo ejemplo aparezca el nombre de una persona real reconduce a la "dedicatoria" del cuaderno azul y hace suponer que la frase "a quien yo sé" muy probablemente se refiera, también, a una persona real. 


\section{Emiliano Mastache}

Tres cosas llaman la atención. La primera es que la anotación está fechada en 1958, lo cual quiere decir que escribir El libro vacío le llevó a Josefina Vicens, por lo menos, cuatro años. ${ }^{10}$ En segundo lugar, resulta inquietante el plural: "mis cuadernos", en la medida en que hace posible, como ya se mencionó, especular sobre si la autora no recurrió a otros cuadernos, además de los dos que aquí analizo, para escribir El libro vacío. Y, en tercer lugar, que la propia Josefina Vicens conciba su esfuerzo escritural como un "camino"; recuérdese que, etimológicamente, ésta es una de las acepciones del término "método".

En ese sentido, no deja de sorprender la contundencia con la que la autora concebía su proyecto escritural: tenía muy claro que su proceso de creación se hallaba circunscrito, fundamental, aunque no exclusivamente, a sus cuadernos.

Ahora bien, esa segunda anotación/dedicatoria hecha por Josefina Vicens en el cuaderno rojo con respecto a sus cuadernos permite imaginar, en sintonía con los planteamientos de Deleuze y Guattari, que el plano del material se fue replicando en el plano de la composición, con base en dicho soporte. ${ }^{11}$

${ }^{10}$ Ese lapso no es definitivo; simplemente, se limita a lo que los cuadernos manuscritos permiten afirmar sin lugar a ninguna duda. Según la propia Vicens, le habría llevado al menos ocho años escribirlo. Por lo demás, cabe especular si las anotaciones/dedicatorias de ambos cuadernos no fueron hechas a posteriori por Josefina Vicens; esto es, una vez que había comenzado a escribir en los mismos o, incluso, cuando ya los había llenado. Aunque, en ese caso, algunos aspectos se volverían un tanto inexplicables, como las fechas, por ejemplo. En lo personal, me inclino a pensar que dichas anotaciones fueron hechas a priori, como un genuino reto de escritura y en forma de dedicatoria a manera de estímulo para la propia autora.

${ }^{11}$ Sobre Deleuze y Guattari, es importante mencionar que los planteamientos que proponen en su admirable texto, "Percepto, afecto y concepto", resultan de gran utilidad en relación con los manuscritos de El libro vacío. Sin pretender agotar esta compleja cuestión, a continuación y a lo largo del texto, destaco algunas de sus ideas más significativas. En un primer momento, los pensadores franceses exponen: "El arte es el lenguaje de las sensaciones tanto cuando pasa por las palabras como cuando pasa por los colores, los sonidos o las piedras. El arte no tiene opinión. El arte desmonta la organización triple de las percepciones, afecciones y opiniones, y la sustituye por un monumento compuesto de perceptos, de afectos y de bloques de sensaciones que hacen las veces de lenguaje. El escritor emplea palabras, pero creando una sintaxis que las hace entrar en la sensación, o que hace tartamudear a la lengua corriente, o estremecerse, o gritar, o hasta cantar: es el estilo, el ‘tono', el lenguaje de las sensaciones [...] El escritor retuerce el lenguaje, lo hace vibrar, lo abraza, lo hiende, para arrancar el percepto de las percepciones, el afecto de las afecciones, la sensación de la opinión" (178). Unas páginas después, precisan: "Las sensaciones, como perceptos no son percepciones que remitirían a un objeto (referencia): si a algo se parecen, es por un parecido producido por sus propios medios, y la sonrisa en el lienzo está hecha únicamente con colores, trazos, sombra y luz. Pues si la similitud puede convertirse en una obsesión para la obra de arte, es porque la sensación sólo se refiere a su material: es el percepto o el afecto del propio material, la sonrisa de óleo, el ademán de terracota, el impulso de metal, lo achaparrado de la piedra románica y lo elevado de la piedra gótica. El material es tan diverso en cada 
En otras palabras, cabe suponer que el soporte utilizado por Josefina Vicens para escribir lo que sería su primera novela (un par de cuadernos) se fue configurando, al paso de la creación y gracias a ella, ficcionalmente en el soporte material del propio

caso (el soporte del lienzo, el agente del pincel o de la brocha, el color en el tubo) que resulta difícil decir dónde empieza y dónde acaba la sensación de hecho; la preparación del lienzo, la huella del pelo del pincel forman evidentemente parte de la sensación, y otras muchas cosas más acá. Cómo iba a poder conservarse la sensación sin un material capaz de durar, y, por muy corto que sea el tiempo, este tiempo es considerado como una duración; veremos cómo el plano del material sube irresistiblemente e invade el plano de la composición de las propias sensaciones, hasta formar parte de él o ser indiscernible" (167).

De manera breve: una de las ideas más valiosas es el hecho de que la remisión fundamental de la sensación es, precisamente, su material. En el caso de la literatura, la primera referencia sería, entonces, la palabra. Sin embargo, esto implica decir también: la sensación del propio decir, del nombrar, del significar y esa extensa serie de fenómenos que el lenguaje verbal hace posibles, pero, sobre todo, implica decir - en relación con una novela como El libro vacío y, aún más, en relación con los manuscritos de la misma que aquí analizo - la sensación del escribir, de la tinta, del papel e incluso de la máquina de escribir y del golpeteo de las teclas con los dedos. En segundo lugar, el reconocimiento de que la sensación incluye - o se incluye enla diversidad de los materiales que intervienen en la realización de la obra constituye una idea de gran relevancia, en la medida en que, sumado al punto anterior de la remisión al material, se vuelve muy difícil determinar dónde comienza y dónde termina la sensación.

En ese sentido, cabe preguntar: ¿Qué sería "preparar" los materiales en el caso de la literatura? ¿Sería algo así como preparar la hoja en blanco? ¿Cómo se haría tal cosa? Interrogantes que tienen una enorme repercusión en relación con El libro vacío. En concreto: si el material de la literatura lo conforman las palabras y la sintaxis, ¿cómo podrían éstas ser "preparadas"? El asunto puede parecer innecesariamente meticuloso, sin embargo, esto significaría que, a excepción de la literatura, las demás artes poseen un margen mucho más amplio para la pre-concepción, elaboración y preparación de los materiales, en la medida en que objetos y soportes diversos son, justo, la materia que requiere trabajarse físicamente con antelación. En radical contraste, el material de la literatura - las palabras - constituye, previa, simultánea y posteriormente a su trabajo estético o artístico, el material del pensamiento y, muy importante, también de la memoria - más adelante, se comprenderá el motivo por el que hago énfasis en este aspecto-, lo cual, entre otras cosas, supone el dilema de su no diferenciación plena. ¿Un trabajo, entonces, hecho con meras palabras?

Como se puede advertir, las ideas de Deleuze y Guattari se conjugan, de manera notable, en la eventual superposición entre el plano del material y el plano de composición, mismos que terminarían por ser indiscernibles. Ahora bien, respecto a El libro vacio, esto obviamente repercute, pero lo hace de forma doble, es decir, tanto en su dimensión diegética (José García y sus cuadernos) como en lo referente a la escritura real (los cuadernos manuscritos de la novela realizados por Josefina Vicens). No obstante, en el primer caso, la escritura de José García no alcanza a concretarse también en un plano de composición; se queda, al parecer, en el puro plano del material. Pero, simultáneamente - y esto es en verdad admirable-, ese ficticio inacabamiento escritural es lo que se constituye en el plano de composición para Josefina Vicens; un plano que, como tal, resulta indiscernible del plano del material en la novela finalmente impresa, pero que es posible apreciar y estudiar, en su cabal autonomía, en los manuscritos de la misma. 


\section{Emiliano Mastache}

protagonista; con la esencial diferencia, claro, de que, en el caso de José García, un cuaderno contendrá sus "estériles" esfuerzos de escritura y el otro permanecerá irremediablemente en blanco - o casi. ${ }^{12}$

No obstante, ese casi juego de espejos que se entabla entre los dos cuadernos manuscritos de El libro vacío y los dos cuadernos de José García no pasa de una extraordinaria y perturbadora coincidencia, porque, tal y como se advirtió al principio, en ambos cuadernos escritos por Josefina Vicens se aborda explícitamente, desde las primeras páginas, la dicotomía ficticia y dispar a que dan lugar los respectivos cuadernos de su personaje.

¿Cómo, entonces, cabría sostener todavía, en relación con El libro vacío, la idea de que "el plano del material sube irresistiblemente e invade el plano de la composición de las propias sensaciones, hasta formar parte de él o ser indiscernible", tal y como lo proponen Deleuze y Guattari?

$\mathrm{Si}$, como se ha señalado, tal cosa no radica, en sentido estricto, en los materiales (sean reales o ficticios), esto es, en los objetos físicos que instrumentalmente hacen posible la escritura - lo cual representaría una reducción demasiado burda y esquemática de la propuesta de Deleuze y Guattari-, esto no quiere decir que no haya, aún, otra dimensión que, sin duda, es física, pero que a la vez entraña, en sí misma, la posibilidad de que una serie de sensaciones, afectos y perceptos cobren vida en una determinada obra. Me refiero al acto creador, sin importar de qué tipo de arte se trate. En efecto, tal y como sucede con Velázquez, que se pinta a sí mismo pintando, o con Escher, que en su litografía compone dos manos que se dibujan de forma recíproca una a la otra, el acto mismo de la creación se vuelve objeto de la creación, es decir, la creación se hace percepto. Y esto es lo que ocurre en El libro vacío, pero, sobre todo, en los manuscritos de la novela, donde la escritura de Josefina Vicens - que, ya se ha dicho, haría las veces del plano del material - deviene, se busca, se tacha, se reescribe, se bifurca, se pierde y se vuelve a encontrar, precisamente, en la escritura perdida de José García - que haría las veces del plano de composición-, hasta hacerse indiscernibles la una de la otra.

Ahora bien, ciertas consideraciones de Deleuze y Guattari sobre el quehacer musical ayudan a concebir lo que sucede en El libro vacio en relación con el acto creador:

$\mathrm{Al}$ respecto, el viejo procedimiento de tema y variación, que conserva el marco armónico del tema, deja paso a una especie de desmarcaje cuando el piano engendra los estudios de

\footnotetext{
${ }^{12}$ Se habrá notado que ese segundo cuaderno de José García sí contiene algo escrito y que no se encuentra en blanco por completo, detalle que no es menor, porque significa que no está, en estricto sentido, vacío, lo cual provoca que la noción de vacio, digamos, en la economía semántica de toda la obra, se refiera necesariamente a algo más que a una cuestión física o espacial (páginas en blanco). Cabe hacer la pregunta, una y otra vez, respecto a la novela: ¿un libro vacío de qué, entonces?
} 
composición (Chopin, Schumann, Liszt): se trata de un nuevo momento esencial, porque la labor creadora ya no se ejerce sobre los compuestos sonoros, motivos y temas, aun a costa de extraer un plano de ellos, sino, por el contrario, directamente sobre el propio plano de composición, para hacer que surjan de él unos compuestos mucho más libres y desmarcados, casi unos agregados incompletos o sobrecargados, en desequilibro permanente (193).

En una palabra, el acto creador se ejercerá ahora sobre el propio plano de composición. En El libro vacío, esto significa que el acto de escribir será el material y, a un tiempo, la composición misma, es decir, se constituirá, de una vez, en bloque de sensaciones tanto en el proceso de creación de Josefina Vicens como en el intento de su personaje que termina por naufragar. ${ }^{13}$ Así, se puede plantear que, en efecto, en el proceso de creación de El libro vacío se fue dando una especie de trasposición paulatina entre ambas escrituras, de manera que una fue aprendiendo de la otra; o, incluso, cabría decir: se fueron leyendo, descifrando y sobreescribiendo mutuamente hasta hacer posible, de modo simultáneo, tanto una novela extraordinaria como un libro vacío.

Finalmente, respecto a la anotación/dedicatoria del cuaderno rojo, no deja de resultar inquietante que quienes firman sean: "Peque" - que, como se sabe, era un apelativo afectivo de la autora hacia sí misma, utilizado también por sus conocidosy "José García". El contraste, en comparación con el cuaderno azul, no podría ser más significativo. En primer lugar, cabe subrayar que la anotación del cuaderno rojo "calca", en cierto modo, la del cuaderno azul: ambas se presentan como dedicatorias y consignan los nombres de quien las suscribe respectivamente. Sin embargo, el hecho de que aparezcan dos nombres, en el caso del cuaderno rojo, revela, además de la doble autoría, una clara conciencia, por parte de Josefina Vicens, de la existencia de dos planos escriturales que, no obstante, se habrían de realizar en una sola escritura. ${ }^{14}$

En otras palabras, esa anotación, en apariencia poco trascendente, constituye un registro de que, cuatro años después de haber empezado a escribir "El Libro Vacío",

\footnotetext{
${ }^{13} \mathrm{El}$ concepto de bloque de sensaciones se debe también a Deleuze y Guattari. Al hablar de qué es lo que conserva y se conserva en el arte, apuntan: "Lo que se conserva, la cosa o la obra de arte, es un bloque de sensaciones, es decir un compuesto de perceptos y de afectos. Los perceptos ya no son percepciones, son independientes de un estado de quienes lo experimentan; los afectos ya no son sentimientos o afecciones, desbordan la fuerza de aquellos que pasan por ellos. Las sensaciones, preceptos y afectos son seres que valen por sí mismos y exceden cualquier vivencia" (164; las cursivas son de los autores).

${ }^{14}$ Por lo demás, no debe pasar desapercibida una diferencia fundamental entre la anotación del cuaderno azul, que posee un evidente tono prospectivo (se plantea hacia el futuro con objetivos a alcanzar), y la anotación del cuaderno rojo, que, en contraste, se asume mucho más como un acto presente y, de cierto modo, también bajo una forma retrospectiva: "en este camino arduo y bello, de mis cuadernos" (las cursivas son mías); lo cual redunda en la idea de que, para 1958, Josefina Vicens había alcanzado, de manera indudable, una clara noción de la doble dimensión autorial y escritural de lo que sería su primera novela.
} 


\section{Emiliano Mastache}

Josefina Vicens había vislumbrado ya, en plenitud, la paradójica unidad estructural de su novela. Acaso el detalle más admirable al respecto no es tanto la mención de ambos nombres ni, propiamente, el orden en que aparecen, sino la conjunción que, de cierta forma, los hace equivalentes. Y esto propongo concebirlo como un doblez o pliegue o flexión de la escritura sobre sí misma - aspecto que retomaré más adelanteDe tal suerte, lo que comenzó como el juego de un hombre que no puede escribir se volvió un tremendo logro literario llevado a cabo por una de las más grandes escritoras mexicanas del siglo Xx.

Hasta aquí el análisis sobre las dos anotaciones/dedicatorias.

\section{Dos pasajes manuscritos}

A continuación, abordaré sólo un pasaje de cada uno de los cuadernos. Al respecto, debo subrayar que en ambos casos se trata de aspectos que, por un lado, modifican y enriquecen sustancialmente la comprensión de El libro vacío, y por otro, permiten observar o, en su defecto, advertir parte del proceso de creación que emprendió Josefina Vicens.

En lo referente al cuaderno azul, es posible afirmar que cuenta con varias secciones bastante diferenciadas entre sí. Haré alusión sólo a la primera de esas partes. La razón principal para centrar la atención en ella, además de su gran relevancia y su indiscutible unidad, es porque dificilmente hay mejor forma de dar a conocer, por primera vez en el ámbito de los estudios literarios en México, un material tan importante como los manuscritos de El libro vacío que adentrarse en ese movimiento inicial de escritura.

La parte que abre el cuaderno azul, fechado en 1954, es un movimiento o periodo compuesto por las 22 primeras hojas - únicamente 11 de ellas poseen algo escrito; como se señaló, la escritura sólo se encuentra en la cara derecha, la izquierda está en blanco- - En ese extenso trecho, Josefina Vicens realiza una especie de disquisición compleja, e inclusive filosófica, del conflicto vivido por José García. Por un lado, el protagonista se pregunta por la conciencia y los límites de ésta; y, por el otro, cuestiona el cuerpo y la propia inercia. Lo más importante es que el conflicto no aparece así en la versión final de la novela publicada en 1958.

Ahora bien, hay algo en ese segundo factor - el cuerpo - que sería ingobernable porque tendría la capacidad de traspasar los límites impuestos por el primero - la conciencia- La página manuscrita dice lo siguiente: 


\section{Los manuscritos de El libro vacío de Josefina Vicens}

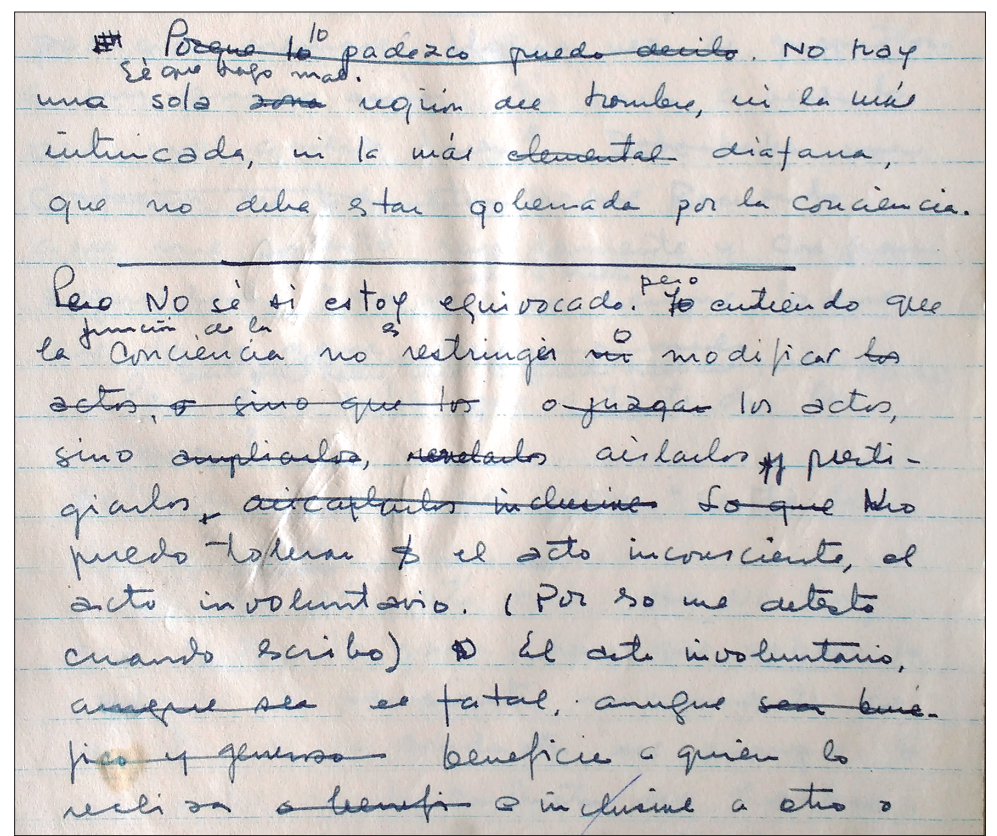

Imagen 3. Pasaje "El gobierno de la consciencia y la escritura". Cuaderno Azul

lo

Porque to padezeo puedo decirlo. NO hay

Sé que hago mal.

una sola zona región del hombre, ni la más intrincada, ni la más elemental diafana, que no deba estar gobernada por la conciencia.

\section{pero}

Pero No sé si estoy equivocado. ¥o entiendo que

función de la es ir o

la conciencia no restringé ni modificar los aetos, o sino que los o juzgar los actos, sino ampliałlos, revelartos aislarlos y prestigiarlos, aeiearlarlos inelusive Lo que xo puedo tolerar el acto inconsciente, el acto involuntario. (Por eso me detesto cuando escribo) $\mathrm{El}$ acto involuntario, aunque sea es fatal, aunque seabene= fieo y generoso beneficie a quien lo realiza o benefi o inckusive a otro $o^{15}$

${ }^{15}$ En la transcripción de este pasaje y en la siguiente — del pasaje incluido en el cuaderno rojo- - , he decidido colocar en otro renglón, generalmente el superior, todas aquellas palabras 


\section{Emiliano Mastache}

El primer axioma, de fuerte raigambre hegeliana, expresado en las cuatro líneas iniciales, postula el primado absoluto de la conciencia por sobre todo aquello que acontece en el interior del hombre. No obstante, es de suma importancia prestar atención a todos los aspectos de la propia práctica escritural. Adviértase que, de inmediato, después de los primeros cuatro renglones, Vicens traza una línea horizontal, como si lo escrito hasta ese punto tuviese que ser repensado o, incluso, reescrito...

Enseguida, nótese cómo, debajo de esa línea, Josefina Vicens retoma el asunto, pero - y esto merece enfatizarse - en un tono mucho menos categórico. Y a continuación, en términos de raciocinio lógico, apunta una consecuencia de ese gobierno total de la conciencia: hay actos que escapan a ello y que, por definición, son involuntarios, entre los cuales - y justo ahí comienza esa especie de autodemérito de José García que recorre la novela - se encuentra nada más y nada menos que la escritura, la cual lo hará, asombrosamente, detestarse.

Ahora bien, tales fenómenos de la escritura pueden ser interpretados en un sentido no necesariamente objetivo o en estricto apego a lo que se observa. Es decir, nada impide proponer lecturas o interpretaciones creativas, y hasta simbólicas, de los diversos acontecimientos escriturales que, justamente, se hacen presentes en un manuscrito literario. La justificación para ello — no sobra recordarlo- se funda en el propósito primordial de la crítica genética, esto es, en la pretensión de reconstruir el proceso de creación literaria de una determinada obra. En esa medida, cabe plantear significaciones múltiples y alternas, sea sobre un aspecto concreto de la escritura, sobre un pasaje o sobre el conjunto de un manuscrito.

Unas páginas antes he aludido a términos como doblez, pliegue o flexión de la escritura sobre sí misma en relación con El libro vacío y los manuscritos de esta novela. Es precisamente en ese sentido que propongo concebir esa, en apariencia, insignificante línea horizontal, o lo que sucede a partir de ella, que aparece en el pasaje sobre la conciencia con el que abre el cuaderno azul.

De tal forma, si se observa la imagen de dicho pasaje con detenimiento, parecería que la línea misma marcara o, de hecho, fuera el límite de la conciencia, la cual, en atención a lo expresado en el propio trecho manuscrito, sólo podría ser superada por la escritura. En otras palabras - permítase una interpretación amplia-, es posible imaginar que esa línea, de cierto modo, hace lo que el texto dice. El cometido fundamental de esta propuesta es llamar la atención sobre ese momento en el que Josefina Vicens escribe unas líneas; enseguida se detiene; traza una raya horizontal que marca

que Josefina Vicens agregó en un segundo momento de escritura o revisión, y he procurado, cuando ha sido el caso, destacar con negritas lo que en el original aparece con otra tinta. Para una mejor comprensión, sugiero hacer la lectura de la transcripción de ambos pasajes en constante comparación con la respectiva imagen. 


\section{Los manuscritos de El libro vacío de Josefina Vicens}

un límite y un fin; y, a continuación, reescribe la idea de manera más extensa. Pero si esto es importante es gracias a que no hay modo de pasar por alto que en ese movimiento de escritura se habla de la propia escritura, y de que se la concibe, precisamente, como algo involuntario y como algo que excede a la conciencia. Esa referencia de la escritura a sí misma es lo que da lugar a una interpretación performativa de dicho pasaje. Por supuesto, no es mi propósito afirmar que la propia Josefina Vicens concibió esa línea horizontal así o siquiera que advirtió la posibilidad de interpretarla de este modo; aún más, es probable que la autora hubiera rechazado semejante perspectiva. No obstante, la escritura no se agota en su literalidad, mucho menos si es de carácter manuscrito y, además, parte de un proceso de creación; por fortuna, en la escritura se hacen presentes, también, acontecimientos que no son necesariamente explícitos o evidentes.

De tal forma, en ese pasaje, algo pulsa casi imperceptible, que no es, en sentido estricto, la conciencia y que, incluso, la excede. Es la escritura, que, en su propio devenir, termina por sobrepasar aquello que, justa y supuestamente, habría de contenerla o "gobernarla".

Acaso esta interpretación peque de microscópica; sin embargo, en mi opinión, subrayar ese sutil movimiento - que, según he mencionado, cabe concebir también como doblez, pliegue o flexión de la escritura sobre sí misma - no sólo entraña una profunda relevancia con respecto a la novela que fue creada a partir de tales esbozos, sino que encuentra pleno sustento en el hecho de que dicho movimiento se constituye en uno de los trazos, en uno de los desplazamientos más inherentemente significativos y productivos de El libro vacío - de nuevo, en relación con ambas escrituras, tanto la de José García como la de Josefina Vicens - Incluso, cabría sostener que es, precisamente, a partir de ese rebasamiento, de ese sobrepasar, de ese excederse la escritura por sobre el sentido, por sobre lo escrito, nombrado y enunciado, y sobre lo pensado, que se va haciendo posible un libro vacío y, al mismo tiempo, un vacío posible en el libro: es de esa forma que la escritura de José García no termina por llenarse nunca y se encuentra en permanente vaciamiento, en continuo imposible.

De tal modo, el manuscrito de El libro vacío abre con el reconocimiento, por parte del personaje, de que algo lo excede y que eso que supera el gobierno de su conciencia es, justo, el escribir. En consecuencia, no deja de llamar la atención sobremanera la frase: "por eso me detesto cuando escribo" - la cual, por cierto, desaparece posteriormente en el mismo cuaderno - Y sorprende porque, de alguna manera, es como si no debiera haber nada más allá de la propia conciencia y, por extensión, como si se debiera rechazar todo lo relacionado con la materia y lo físico - incluido (adviértanse las diversas repercusiones) el propio cuerpo.

Para quien se ha sumergido en las profundidades y retruécanos de El libro vacío, esta oposición entre conciencia y cuerpo no resultará del todo desconocida, porque, 


\section{Emiliano Mastache}

probablemente, la reconocerá en la novela, pero bajo otra forma. En efecto, Josefina Vicens tuvo el gran acierto de componer esa disquisición cuasi filosófica, que inaugura su primer cuaderno manuscrito, en términos no sólo más coloquiales, sino, sobre todo, más vívidos.

Esa oposición entre conciencia y cuerpo termina por traducirse en la atormentada duplicidad que vive de manera constante José García entre dos "yos", misma que se hace presente casi desde la primera página y en varios momentos a lo largo de la novela. De esa forma, el conflicto de José García, que ciertamente podría resultar un tanto extravagante para no pocos lectores, se vuelve algo universal al fundarse en el choque entre la voluntad de hacer algo y la imposibilidad de lograrlo.

Ahora bien, es conveniente mencionar que, comparados con el texto publicado, varios pasajes en los dos cuadernos manuscritos de El libro vacío constatan esa transición - realizada magistralmente por Josefina Vicens-, que va de lo filosófico o lo abstracto a lo cotidiano y a aquello que se padece en la propia carne. ${ }^{16}$ En otras palabras, ese extenso pasaje de 11 páginas - que concibo como una especie de disquisición filosófica y que da inicio al cuaderno azul de 1954- es de un incalculable valor, porque, entre muchas otras cosas, ayuda a vislumbrar, en retrovisión o, si se prefiere, en flashback, la forma agudamente filosófica y, más bien, conceptual en la que Josefina Vicens comenzó a escribir su insuperable primer novela. El breve pasaje que he analizado es sólo una pequeña muestra de la relevancia que tienen los manuscritos de El libro vacío, dado que permiten postular que el proceso de creación de Josefina Vicens puede caracterizarse como un trayecto que fue de lo abstracto, y hasta dialéctico - en su sentido filosófico más riguroso-- a lo vivencial y lo corpóreo. La propia autora se percató, mediante su labor escritural, realizada reflexiva y meditadamente a lo largo de por lo menos esos cuatro años, de la necesidad de, en una palabra, hacer más mundano y humanizar el dilema esencial que había concebido de modo primigenio entre la conciencia y aquello que no responde a ella y que se le escapa. ${ }^{17}$

${ }^{16}$ De acuerdo con Aline Pettersson: "Es difícil entender la manera tan eficaz en que ella [Josefina Vicens] construye a José García - el personaje-, un empleado mediocre, de vida asimismo mediocre. Y cómo a partir de esta situación tan poco heroica, Vicens consigue elevar sus reflexiones sin traicionar nunca a José García. Sorprende que el lector se reconozca en un individuo anodino y que haga suyos los vericuetos mentales que lo recorren. De la elección de cada una de las palabras que conforman la novela, entre los muchos niveles en los que se puede leer, destaco el lenguaje permeado por la humildad del personaje — que lo hace a él crecer y redondearse - y la altura de quien escribe en realidad: Vicens. No se trata de una yuxtaposición. Son las mismas palabras y no lo son, todo depende de si se mira al lado de García o al de su autora. Finalmente se trata de una indagación filosa sobre el acto mismo de escribir" (26).

${ }^{17}$ Como se puede advertir, sin ser excluyente, sino al contrario, la hipótesis que aquí propongo se plantea en un sentido diferente al comentario de Aline Pettersson: antes que "elevar 
Y la manera en que resolvió tal dilema - no sobra enfatizarlo- es, sin duda, magistral: la novela publicada en 1958; justamente, un drama en forma de contienda interna vivido por un hombre llamado José García, que se debate entre un yo que quiere escribir, que le mandata escribir, y un yo que no consigue hacerlo. De ese modo, el lector difícilmente llega a percibir el problema de José García como un dilema intelectual o filosófico; por el contrario, el gran mérito de Josefina Vicens consiste en lograr que, desde la primera página, el lector se adentre con viveza en el dilema esencial y también existencial del protagonista y que llegue a sentirlo, en buena medida, como propio, dado que lidia con algo absolutamente común: la imposibilidad de realizar un impulso que reclama ser consumado.

Hasta aquí lo que respecta al pasaje manuscrito del cuaderno azul.

A continuación, analizaré un pasaje del cuaderno rojo de 1958. Pero antes, es preciso subrayar que, si en el cuaderno azul pueden distinguirse varias secciones con bastante claridad, en el caso del cuaderno rojo esto se vuelve más difícil de discernir, en principio, porque cuenta con más páginas manuscritas, pero, sobre todo, porque la escritura y la reescritura de los pasajes se hacen más complejas.

El pasaje que destaco forma parte de un extenso periodo de escritura comprendido por más de veinte páginas. Es una asombrosa e inquietante reflexión hecha por José García acerca de si los recuerdos y la memoria podrían ser o no la materia prima y el andamiaje para su ansiado libro. No obstante, vale decirlo desde ahora: la reflexión fue retirada por Josefina Vicens de la versión final. En efecto, los recuerdos aparecen en la novela publicada en 1958, pero de un modo por completo distinto, porque, antes que constituir el objeto de la narración, operan como una especie de negativo de la memoria, en la medida en que, para José García y su escritura, terminan por volverse mucho más importantes los deseos y los anhelos no realizados que los hechos en realidad vividos — lo cual, si se piensa con detenimiento, también representa otra forma de la memoria.

En contraste, el pasaje del cuaderno rojo dice lo siguiente:

sus reflexiones sin traicionar" a su personaje, Josefina Vicens, en mi opinión — basada en los manuscritos - "hizo descender" sus primeros trazos a la justeza y llana condición de José García para hacer posible su novela, lo cual, si se observa con detenimiento, deja entrever un notable y meticuloso trabajo de escritura y reescritura por parte de la autora; al contrario de lo que su personaje, supuestamente, no hace y no sabe hacer. 
Emiliano Mastache

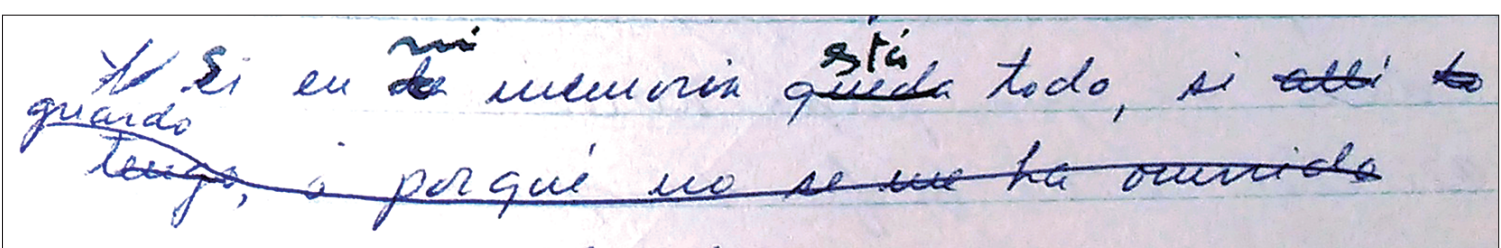

gever becolando of uo

elle Laita contu ui voluntad un quacda

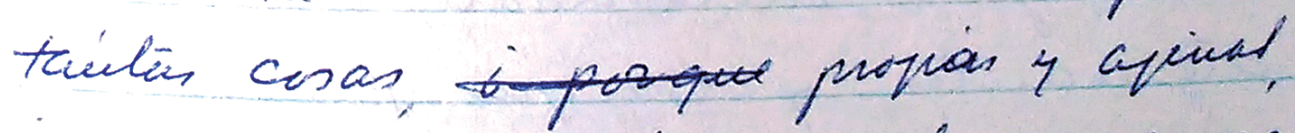
- por qui wo ne twe tow vovido que tour.

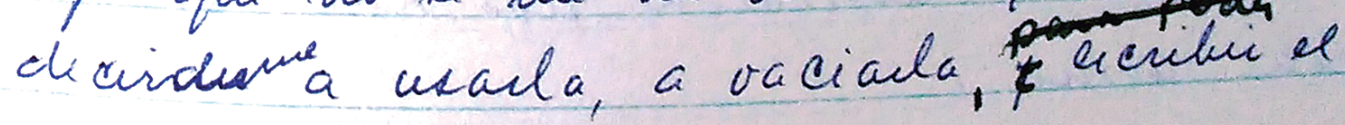
y

Imagen 4. Pasaje "Consciencia y escritura"-A. Cuaderno Azul

libro con el matevial que tla we po. porcine? Hichos Revitive ho has hecho; wo todos tienen la imaguiacion vecua. via para inquetar, 7, no destante han $b_{0}$. grado lo que he proponian y hau connors. do a sur lectiver con el fil niat ol su recuerdos. Wo decien uada mus wi

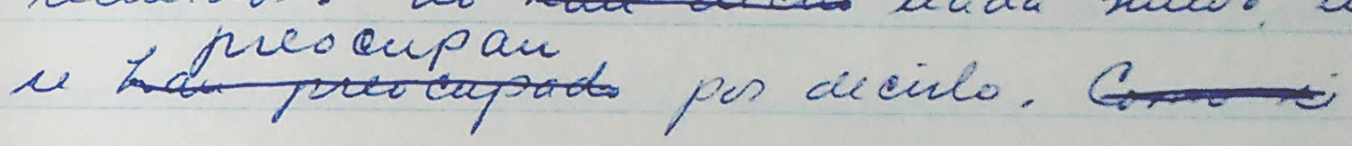

Imagen 5. Pasaje "Consciencia y escritura"-B. Cuaderno Azul

80 (an)ecdótica * vol. IV, núm. 2, julio-diciembre 2020 


\section{mi está}

Y si en la memoria queda todo, si allí lo

guardo

tengo, ¿pōr-qué

que es recordando y no

ella hasta contra mi voluntad me guarda

tantas cosas iporqué propias y ajenas

¿ por qué no se me ha ocurrido que es recor-

dirme parapoder

decir a usarla, a vaciarla, y escribir el

$\mathbf{y}$

libro con el material que ella me aporte proporcione? Muchos escritores lo han hecho, no todos tienen la imaginación para crear necesaria para inventar, y, no obstante, han logrado lo que se proponían y han conmovido a sus lectores con el fiel relato de sus vidas o con el de otras o de las de otros dicen

recuerdos. No han dicho nada nuevo ni preocupan se han preocupado por decirlo. Gomo si

Tres detalles resultan, en particular, significativos. El primero — no se puede dejar de advertir - es que se piensa, precisamente, en vaciar la memoria como posibilidad para escribir. ${ }^{18} \mathrm{El}$ segundo tiene que ver con la brevísima y, en apariencia, inofensiva expresión: "el fiel relato de sus [...] recuerdos", en la medida en que en ella subyace una concepción de la escritura mucho más elaborada y mucho menos ingenua de lo que podría creer cualquier lector de El libro vacío. No, no es que los recuerdos vayan a ser transcritos de manera directa, sino, más bien, que en el pasaje se concibe una mediación o, mejor dicho, un otro doblez o pliegue de la escritura que consiste en relatar los recuerdos. Así, la escritura posee al menos dos grandes dimensiones: la del acto

${ }^{18} \mathrm{El}$ lector, sin duda alguna, reconocerá la importancia que tal idea entraña, aunque de modo inverso, en relación con el proyecto escritural de José García. Esto es: en los manuscritos se considera la posibilidad de vaciar algo (la memoria) para poder escribir; en la novela, al contrario, se buscará llenar el vacío con algo (las palabras) como única vía - trunca - de la escritura, lo cual expresa, de manera profunda, otro aspecto fundamental del proceso de creación de El libro vacio por parte de Josefina Vicens. 


\section{Emiliano Mastache}

mismo de relatar y la de lo que ha de relatarse. El otro detalle de gran repercusión es que a la memoria se la contempla o considera como potencial detonante de la escritura en los manuscritos, lo cual, ipso facto, desvela una posible filiación literaria del protagonista. Sin duda, sería proustiano. ${ }^{19}$

Ahora, una novela de tal densidad como El libro vacío se presta, con facilidad, a asociaciones de diversa índole: se puede considerar, por igual, heredera de Mallarmé, de Flaubert o de André Gide, por aludir a algunos nombres. No obstante, la filiación más destacada, desde mi perspectiva y con base en el conocimiento de los manuscritos de la novela, es la de Proust. En ese sentido, se podrían referir infinidad de consideraciones, pasajes y extensas inquisiciones, todas con no poca validez; pero sólo mencionaré dos aspectos. El primero es indirecto. Se trata de un breve planteamiento hecho por José Ortega y Gasset, en 1925, en su más o menos olvidado ensayo "Ideas sobre la novela", sobre el autor de En busca del tiempo perdido. Al respecto, señala:

En Proust, la morosidad, la lentitud llega al extremo y casi se convierte en una serie de planos estáticos sin movimiento alguno, sin progreso ni tensión. Su lectura nos convence de que la medida de la lentitud conveniente se ha traspasado. La trama queda casi anulada y se borra el postrer resto de interés dramático. La novela queda así reducida a pura descripción inmóvil, y exagerado con exclusivismo el carácter difuso, atmosférico, sin acción concreta que es, en efecto, esencial al género. Notamos que le falta el esqueleto, el sostén rígido y tenso, que son los alambres del paraguas. Deshuesado el cuerpo novelesco se convierte en nube informe, en plasma sin figura, en pulpa sin dintorno (44).

¿No resultan esa "morosidad", esa "lentitud", esos "planos estáticos sin movimiento" y "sin progreso" algo extrañamente próximo a la escritura de José García y su imposibilidad? ¿No puede decirse de El libro vacío que en él "la trama ha quedado anulada", que se ha borrado "el postrer resto de interés dramático" y que "la novela ha quedado reducida a pura descripción inmóvil"?

No se debe ignorar que el ensayo de Ortega y Gasset es una apasionada disquisición acerca del estado del arte de la novela en aquel momento, respecto a la cual, por cierto, el pensador español no se mostraba muy esperanzado, sino al contrario. Baste recordar planteamientos como el siguiente: "A mi juicio, esto es lo que hoy acontece

${ }^{19}$ En seguida, hago mención de algunos escritores que podrían asociarse directamente con El libro vacío. Al respecto, debo decir que el Dr. Armando Pereira, en una conferencia magistral sobre El libro vacio, presentada a finales de 2018 en el Instituto de Investigaciones Filológicas, se adentró en esas posibles filiaciones de la novela, entre las que destacó la figura de Mallarmé y su multicitada página en blanco; además de otros autores, en especial, franceses. No niego tales filiaciones; sin embargo, como se verá, me parece que la figura de Proust juega un papel determinante, y merece, por ello, destacarse en relación con la primera novela de Josefina Vicens. 


\section{Los manuscritos de El libro vacío de Josefina Vicens}

en la novela. Es prácticamente imposible hallar nuevos temas. He aquí el primer factor de la enorme dificultad objetiva y no personal que supone componer una novela aceptable en la presente altitud de los tiempos" (34). Tal parecería que José García es una admirable encarnación de esa falta de tema. No es, pues, descabellado imaginar que algún antecedente de El libro vacío se encuentra en ese texto de Ortega y Gasset y, en general, en su pensamiento. Resulta muy probable que Josefina Vicens lo haya tenido entre sus lecturas y autores más preciados.

En esa dirección, jugando con las asociaciones y regresando a Proust, bien cabría repensar el título de El libro vacío en clave proustiana, como, por ejemplo: En busca del libro perdido o, claro: En busca de la escritura perdida. Aunque, ciertamente, los rejuegos podrían extenderse. Nada impide que la primera novela de Josefina Vicens pudiera imaginarse, en alusión a Beckett, también bajo el nombre: Esperando al libro o Esperando a la escritura - en principio, una mera asociación, pero que, si se piensa con detenimiento, abre la posibilidad de considerar la escritura de José García, tal y como se calificó el teatro de Beckett, como una escritura del absurdo.

Pero dejo las posibles asociaciones y vuelvo al segundo aspecto que deseo destacar sobre el pasaje incluido en el cuaderno rojo de Josefina Vicens, en el cual se aborda la memoria. Como se aprecia en el breve trecho manuscrito, quien escribe se pregunta con viva inquietud si no está o estaría en la memoria, justamente, el material necesario para escribir su libro, de modo que sólo bastaría con "vaciarla" de su contenido - esto es, los recuerdos-, tal y como "muchos escritores lo han hecho"; aunque, acota enseguida, quizá no hayan dicho nada nuevo.

Sin embargo, en paralelo, debe subrayarse el hecho de que en la reflexión se opone la invención a la memoria. El razonamiento es, más o menos, el siguiente: dado que no todo escritor puede inventar, bien puede recurrir a la memoria. En esa dirección, resulta inevitable aludir a lo que José García apunta en un pasaje de la novela, que retomo, in extenso, más adelante: "La verdad es que yo no puedo inventar algo ni a alguien y entonces necesito llenar con palabras ese hueco, ese vacío inicial” (43).

De esa forma, la incapacidad para inventar, que en el manuscrito se considera susceptible de ser superada con el recurso de la memoria y los recuerdos, termina, en la novela, por ser la detonante para, precisamente, llenar con palabras el vacío, lo cual, en tensión con lo que he planteado, podría interpretarse, incluso, como una superación, hasta cierto punto, de los tópicos más típicamente proustianos por parte de Josefina Vicens y la escritura de y en El libro vacío.

Por lo demás, el planteamiento hecho en el pasaje manuscrito del cuaderno rojo, sin duda, convoca a tomar postura y a entregarse a la polémica de los cruces posibles entre memoria, vida y ficción. Múltiples cosas podrían decirse al respecto. Sin embargo, en vez de ello, me centraré en algunas ideas de Proust. 


\title{
Emiliano Mastache
}

En un texto breve, llamado "Swann explicado por Proust", el reconocido escritor consigna algunas opiniones sobre su novela que son verdaderamente reveladoras. En primer lugar, merece ser destacado, en cuanto a la morosidad señalada por Ortega y Gasset, pero, sobre todo, con respecto a la des/escritura de José García y El libro vacío, en tanto proyecto escritural de Josefina Vicens, la honda conciencia que Proust tenía sobre su tentativa estética y su relación con el problema del tiempo. El autor francés dice:

Sólo publico un volumen, Por el camino de Swann, de una novela que tendrá como título general En busca del tiempo perdido. Hubiera querido publicarlo todo junto, pero ya no se editan obras en varios volúmenes. Soy como alguien que tiene una alfombra demasiado grande para las viviendas actuales y no tiene más remedio que cortarla.

Jóvenes escritores por los que siento simpatía preconizan por el contrario una acción breve con pocos personajes. No es la forma en que yo entiendo la novela. ¿Címo explicarlo? Sabe que hay una geometría plana y una geometría en el espacio. Para mí, la novela no es únicamente psicología plana, sino psicología en el tiempo. He tratado de aislar esta sustancia invisible del tiempo, pero para hacerlo necesitaba una experiencia que pudiera durar (131).

Parecería que Josefina Vicens tuvo la capacidad de vislumbrar en la imposibilidad de escribir de José García una experiencia que pudiera durar. Claro, la finalidad no necesariamente consistió, como para Proust, en aislar la sustancia del tiempo. Por el contrario, lo que estaría en juego, en El libro vacío, sería la sustancia del espacio; pero lo estaría a través de la palabra, una palabra que cobra cuerpo, que se hace materia: que se encarna a través de la palabra escrita, misma que - constituye uno de los momentos más sublimes de la novela - se ha propuesto llenar con palabras el vacío inicial. José García escribe:

\begin{abstract}
¿Qué puede contar de su vida alguien como yo? Si nunca, antes de ahora, le ha ocurrido nada, y lo que ahora le ocurre no puede contarlo porque precisamente eso es lo que le ocurre: que necesita contarlo y no puede. Pero no se trata de sucesos, de acontecimientos con fecha, personajes y desenlace. No. ¿Cómo decirlo? Se trata de escribir y entonces, necesariamente, hay que marcar un tema, pero más que marcarlo, porque no tengo el tema que interese a todos, hay que desvanecerlo, diluirlo en las palabras mismas. ¡Otra vez las palabras! ¡Cómo atormentan! La verdad es que yo no puedo inventar algo ni a alguien y entonces necesito llenar con palabras ese hueco, ese vacío inicial. Pero con tales palabras, tan convincentes, que no se perciba la existencia del hueco. Que no sea un ir poniendo, rellenando, dejando caer, sino un transformar, hasta que sin tema, sin materia, el vacío desaparezca (43).
\end{abstract}

Tal y como se subrayó, aquí se hace patente que la escritura de José García se propuso de manera inversa a lo que ocurre en los manuscritos de la novela: en vez de vaciar la memoria como posible vía para la escritura, llenar con palabras el vacío. 
El otro gran planteamiento de Proust es expresamente sobre la memoria, en relación con la cual hace un deslinde fundamental:

mi obra está dominada por la distinción entre memoria involuntaria y memoria voluntaria [...] Para mí, la memoria involuntaria, que es sobre todo una memoria de la inteligencia y de los ojos, sólo nos da del pasado aspectos sin veracidad, pero si un olor, un sabor recuperados en circunstancias muy diferentes, despiertan en nosotros a nuestro pesar el pasado, nos damos cuenta de hasta qué punto este pasado era diferente de lo que queríamos recordar, lo que dibujaba nuestra memoria voluntaria, como los malos pintores, con colores sin veracidad. En este primer volumen, el narrador, que habla en primera persona (y que no soy yo) recupera de repente años, jardines, seres olvidados en el sabor de un sorbo de té en el que ha mojado un trozo de magdalena; sin duda lo recordaba todo, pero sin color, sin encanto (132-133).

Un poco después, agrega: "Yo creo que el artista sólo debería pedir a los recuerdos involuntarios la materia prima de su obra. En primer lugar, precisamente porque son involuntarios, se forman solos, atraídos por una semejanza de un instante, tienen un cuño de autenticidad" (133).

Adviértase la profunda coincidencia entre los "recuerdos involuntarios" de Proust y el acto de escribir también involuntario presente en los manuscritos de El libro vacio. De esta suerte, la alusión a la memoria que aparece en el cuaderno rojo de los manuscritos de El libro vacío, y que también termina siendo excluida por Josefina Vicens en la versión final, no podría resultar más elocuente. Es casi innegable que en dichas especulaciones sobre la memoria como material de la escritura subyace una lectura de Proust y una comprensión de la literatura en ese sentido. ${ }^{20}$ En consecuencia, planteo que esta posible evocación de la obra del autor francés muy probablemente se volvió,

${ }^{20}$ Si bien la lectura de la obra de Proust por parte de Josefina Vicens no es una cuestión que se pueda afirmar de manera contundente, existe una alta probabilidad de que así haya sucedido, con base en, al menos, dos hechos. En primer lugar, para 1954, cuando Josefina Vicens comenzó el cuaderno azul (no se diga el cuaderno rojo de 1958), Marcel Proust era ya una figura absolutamente consagrada a nivel mundial, gracias a Por el camino de Swann. En segundo lugar y mucho más importante, la viabilidad de pensar en Proust en relación con los manuscritos de El libro vacio se encuentra en el pasaje que he destacado. Es la propia Josefina Vicens quien establece la conexión entre memoria y escritura y, aún más, quien asocia esa posibilidad con escritores concretos al decir: "Muchos escritores lo han hecho, no todos tienen la imaginación [...] necesaria para inventar y, no obstante, han logrado lo que se proponían y han conmovido a sus lectores con el fiel relato de sus [...] recuerdos". Por lo demás, la alusión a Proust se basa en el hecho de que la memoria, como ya lo he subrayado, no sólo es un tema fundamental en la novela de Josefina Vicens, sino que en los propios manuscritos constituye un aspecto de primer orden: al paso de la escritura y la(s) reescritura(s) es posible apreciar la forma en que el tópico de la memoria sufre múltiples transformaciones. Desafortunadamente, por motivos de espacio, tendré que profundizar en esta cuestión en otro momento. 


\section{Emiliano Mastache}

a los ojos de Josefina Vicens, algo insostenible en relación con su querido José García y, por ello, fue preciso no incluir dicho pasaje.

Para decirlo de manera puntual: ese particular tratamiento de la memoria realizado en el manuscrito necesariamente provoca un vuelco en la concepción que, a partir de la lectura de la novela, se tiene del protagonista, porque en El libro vacío se presenta a José García como un hombre medio, quien posee una escasa, si no es que nula, cultura letrada. Pero, en radical contraste con la novela, en el pasaje del cuaderno rojo se habla de lo que suelen hacer y han logrado los escritores al tomar como objeto sus vidas, las vidas de otros o sus recuerdos; es decir, ello implicaría que José García sería, entonces, un lector más o menos asiduo y, en especial, un lector de literatura.

Se comprenderá ahora la enorme relevancia de que en todo El libro vacío no exista una sola cita propiamente literaria de una obra o de un autor, ni siquiera una cita de carácter ideológico o religioso, ni la alusión a un nombre. Las únicas citas que hay en toda la novela son: de palabras escritas por José García; de palabras pensadas por él; o de palabras pronunciadas por otros personajes en momentos y espacios diversos. Tales citas se identifican con facilidad gracias al uso de las comillas. Al respecto, es importante señalar que dicho signo ortográfico juega, en El libro vacío, un papel fundamental, en la medida en que constituye uno de los modos en que la escritura de José García se busca a sí misma — se flexiona o se pliega o se dobla sobre sí misma - sin lograr encontrarse, y termina reconduciéndose, sin remedio, a su propia imposibilidad.

¿Qué otra cosa podría suceder con una palabra que no ha podido más que recurrir a sí misma para citarse eventual, pero reiteradamente? ${ }^{21}$

Más allá, en términos del perfil medio o no letrado de José García, vale la pena agregar que en los manuscritos hay un pasaje sumamente inquietante, dado que, en él, quien escribe declara trabajar, nada más y nada menos, que como ayudante en una imprenta. ¿Cuál es la razón para que Josefina Vicens haya decidido omitir también esa parte en la versión final de su reconocida novela?

Si bien no es posible sostener que para laborar en una imprenta se requiera mayor condición letrada, resulta un tanto impensable que, a mediados del siglo xx, un ayudante de imprenta no tuviera, al menos, una mínima inclinación por la lectura y, quién sabe, incluso por la propia escritura. ${ }^{22}$ De tal modo, es muy probable que

\footnotetext{
${ }^{21}$ En consecuencia, cabe plantear: ¿no es esa flexión o doblez de la escritura sobre sí misma aquello que José García - aunque él se refiere a una dimensión temática - quiere evitar a toda costa, es decir, una escritura "en primera persona", de la cual tanto desea escapar, pero en la que termina cayendo inevitablemente una y otra vez?

${ }^{22}$ Ciertamente, esto resultaría casi del todo inconcebible en el siglo xx, empero, en el caso de los siglos previos, tal circunstancia no es así. No se debe omitir el hecho desconcertante de que el primer impresor del que se tiene noticia en América, Juan Pablos - a quien, por encargo del connotado Juan Cromberger, se le encomendó, precisamente, abrir una imprenta en este
} 
Josefina Vicens retirara también ese detalle de la versión publicada porque habría dado a su protagonista una dimensión y una connotación mucho más complejas de lo que, al final, resulta ser José García. O, para decirlo en otras palabras, haber dejado ese aspecto en la novela - el trabajar en una imprenta - habría hecho poco verosímil que el protagonista no tuviera otros recursos para escribir.

Empero, bien vista, esta cuestión posee repercusiones de gran alcance. Como cierre del presente apartado, sólo mencionaré una de ellas. Me refiero a la posibilidad de establecer, tanto en lo relativo a José García como en general, una correlación entre el escribir - y escribir un libro lleno- y los conocimientos que se tienen o no en torno a la cultura letrada (la figura canónica del llamado "hombre de letras" sería paradigmática en ese sentido). O expresado de otra forma, cabe preguntar: ¿En qué medida el bagaje y las lecturas realizadas por una persona determinan su capacidad de escribir literariamente?

$\mathrm{Al}$ respecto, en El libro vacio sólo hay tres momentos en los que José García alude a algún tipo de lectura y a una noción incipiente de la escritura: por un lado, reconoce que recurre o ha recurrido al diccionario para revisar la ortografía de ciertas palabras; y, por otro, especula sobre la posibilidad de comenzar por escribir un cuento para buscar que sea publicado en un periódico. De modo que José García sí posee diversos registros de lectura, pero en ningún caso se trata de una cuestión propiamente literaria, salvo el referido cuento - mismo que, por cierto, el lector no sabrá si llegó a existir-. De manera paralela, lo reitero, como tal, no se menciona un solo libro - vaya, ¿Coincidencia? - en todo El libro vacío. Por consiguiente, en estricto sentido, no hay forma de saber si José García cuenta, de hecho, con algún modelo a seguir, a imitar o a superar (algún libro que él mismo considere lleno), o si, simplemente, no lo tiene y ha sido presa de un deseo de escribir más allá de un referente semejante. Por supuesto, visto con detenimiento, resulta poco creíble que no tenga ni un solo modelo. Para decirlo con toda claridad: de haber mencionado algún libro, cualquiera que fuera, José García habría fijado un horizonte de lo posible y, entonces, se le podría achacar el no haber intentado siquiera imitarlo. No obstante, al leer la novela, dicho detalle pasa por completo desapercibido — algo, en verdad, admirable- Y s si esto ocurre así

continente-, al parecer reconoció en un documento, pocos años antes de llegar a estas tierras, que era analfabeta. Tal y como lo consigna Tomás Granados Salinas: "Juan Pablos es la forma castellanizada del nombre Giovanni Paoli, natural de la pequeña ciudad lombarda de Brescia. No se sabe a ciencia cierta qué hizo antes de aceptar el ambicioso encargo de Cromberger: quizá fue aprendiz en Venecia o Lyon, como era usual entre la gente de imprenta, o asistió a alguna universidad italiana, donde habría aprendido latín - en dos de los libros impresos en su taller hay sendas notas introductorias redactadas por él, en las que se nota el domino de esa lengua-, aunque hay quien dice que al firmar el contrato que lo condujo a México apenas sabía escribir su nombre - en un documento de 1532 Pablos reconoce ser analfabeta" (67). 


\section{Emiliano Mastache}

es gracias - no debe minimizarse - a la enorme capacidad de una escritora como Josefina Vicens, quien tuvo la paciencia y la dedicación de revisar meticulosamente sus propios manuscritos y versiones hasta lograr hacer imperceptibles ciertos aspectos que, como éste, resultan relevantes - lo cual se aprecia con plenitud al estudiar los manuscritos de El libro vacío. ${ }^{23}$

Por último, no es ocioso apuntar que, en tanto personaje, José García se encuentra muy próximo a dos figuras fundamentales de la literatura. Por un lado, a Bartleby, el inquietante personaje de Melville, quien es un copista; y, por el otro, a uno menos reconocido: Bernardo Soares de Pessoa ${ }^{24}$ La aproximación obvia entre los tres personajes se debe, en principio, a que los tres escriben; sin embargo, me parece de enorme relevancia subrayar que su condición lectora y los registros que cada uno posee merecen igual tratamiento.

\section{Breve conclusión}

$\mathrm{Al}$ estudiar los cuadernos manuscritos de El libro vacío, como es natural, llaman la atención una serie casi infinita de detalles y aspectos. No obstante, en plena correspondencia con lo planteado a lo largo de este trabajo, propongo la siguiente hipótesis: al paso de la lectura de los manuscritos, si algo resulta cada vez más evidente es que, al escribir lo que representaría una de las novelas más destacadas del siglo xx en el ámbito de la literatura mexicana, Josefina Vicens fue advirtiendo que no podría sostener a un José García, por un lado, con perfil medio, y por el otro, sostenerlo tal cual, en su imposibilidad de escribir, y, al mismo tiempo, hacerlo partícipe de la cultura letrada y

${ }^{23}$ Si hubiere aún alguna duda sobre ese cuidadoso proceso de edición por parte de Josefina Vicens en relación con las alusiones a lecturas posibles, baste con agregar que en el primer pasaje del cuaderno azul de los manuscritos, esto es, en las primeras páginas y como parte de ese intenso discurrir filosófico, el personaje escribe: "Probar al hombre. Al puro. Realmente no puedo entenderlo. Y menos cuando leo eso que sólo al cuerpo pertenece: glándulas, secreciones, conformaciones especiales". De modo que José García contaría así con un otro registro de lectura, a partir de una fuente de carácter médico, anatómico o biológico, en una palabra, de carácter científico. Sin embargo, sucede que este pasaje fue eliminado también por su autora y no aparece en la versión definitiva de El libro vacio, lo cual refuerza y, sobre todo, demuestra que Josefina Vicens decidió suprimir cualquier referencia a la lectura en su novela, pero, valga insistir: no sólo descartó las referencias literarias, sino absolutamente todas, puesto que, conforme a lo que propongo, de haberlas mantenido, su protagonista tendría otro carácter y otros horizontes que harían insostenible una cierta imposibilidad de escribir. $\mathrm{O}$, para decirlo de manera inversa: es a través de esa serie de descartes que el acto de escribir consigue hacerse presente en El libro vacío, antes que cualquier otra cosa, como una irrefrenable pulsión de hacerlo, como necesidad desnuda, ya sin adjetivos.

${ }^{24} \mathrm{Al}$ respecto, véase el ensayo de Alberto Vital (2017). 
libresca, ni siquiera en un grado mínimo (ni, aun, como ayudante en una imprenta). En otras palabras, la autora tuvo que enfrentar el hecho de que ambos trazos eran simplemente irreconciliables. ${ }^{25}$ Pero esto es importante no sólo en términos estructurales o en términos de cómo caracteriza a su personaje, sino que dicha tensión le representó el tener que des-solemnizar su propia escritura, sus primeros esbozos manuscritos, y procurara darles un tono menos filosófico y abstracto, en aras de uno mucho más coloquial, más próximo a un hombre medio de la Ciudad de México en los años 50, que, sin saber bien a bien cómo ni por qué, siente el irrefrenable impulso de escribir.

Esa es la razón por la cual no se incluyeron en la versión final los dos pasajes que aquí he abordado: la disquisición de tono filosófico sobre la dicotomía conciencia y cuerpo, que forma parte del cuaderno azul; y la especulación sobre si la memoria podría ser el motivo, el tema y el material de su escritura, que se encuentra en el cuaderno rojo. Ambos, a su modo, fueron magistralmente reformulados por Josefina Vicens mediante un trabajo paciente y dedicado de revisión y reescritura.

Así es como, en concordancia con los planteamientos de Deleuze y Guattari, el plano del material (los manuscritos de Josefina Vicens) invadió de manera progresiva el plano de composición (los cuadernos de José García) en el proceso de creación de El libro vacio. No, por cierto, por medio de la réplica casi a la letra o de la trasposición, en la ficción, de un par de cuadernos, sino mediante la escritura como percepto, como afecto y como concepto, compuesta en bloques de sensaciones.

No es, pues, la mera palabra el material desde el que se erige la (no)escritura de $E l$ libro vacío. Claro, resulta innegable que la palabra constituye el material de la escritura, pero - no hay distinción - es el material de cualquier escritura.

La lección acaso más invaluable de los manuscritos de una obra como El libro vacio consiste en advertir que, en primera instancia, el acto de escribir se ha hecho material de sí mismo. Pero esto significa que la propia escritura se ha constituido como material, también, a partir de sus hiatos e inadecuaciones, de sus imposibilidades y cuestionamientos, de sus abismos y sus tachaduras y bifurcaciones... de sus vacios...; y, particularmente, que ha amasado ese material a partir de sus posibles simientes y detonantes, tal y como lo muestran tanto el discurrir filosófico con el que Josefina Vicens comenzó a elaborar su magnífica novela como la elucidación de inspiración proustiana sobre la memoria que aparece en el segundo cuaderno manuscrito.

${ }^{25}$ No se debe olvidar que, en la entrevista realizada por Daniel González Dueñas y Alejandro Toledo, la autora manifiesta lo siguiente en relación con su personaje: "Tiene un problema que ni siquiera es literario. Él necesita escribir. No piensa 'voy a hacer literatura'; se dice: 'voy a expresarme, tengo necesidad de decir algo'” (35; las cursivas son de los autores). 


\section{Emiliano Mastache}

En una palabra, la importancia de ambos pasajes radica en su ausencia en la versión publicada; o, mejor, su trascendencia radica en su admirable reescritura y recomposición a manos de Josefina Vicens. Por un lado, una dicotomía - también, como quería Girondo, incruenta - entre la conciencia y el acto involuntario, ingobernable, de escribir, compuesta coloquialmente bajo la forma de un conflicto interno entre dos "yos". Y, por el otro, un recurso a la memoria que, no habiendo alcanzado las hazañas más elementales, se reconvierte como contra sí misma, y en ese vivo recordar lo que nunca llegó a suceder encuentra una inusitada posibilidad para escribir, indefinida y morosamente, que no tiene, de hecho, nada que escribir.

¿Cómo se llena, pues, el vacío? Acaso con una sola palabra que se extiende (y se pliega y se dobla) a sí misma/sobre sí misma, esperando hallarse, por fin, de alguna forma, pero que, en ese mismo movimiento, se hace posible de imposible:

\section{"Escribo... Escribo que escribo... Escribo que no escribo..." "Escribo que escribo que no escribo".}

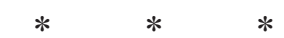

Antes que procurar hacer un mero registro técnico de correcciones y descartes - lo cual, en atención a una cuestión elemental del método propiamente ecdótico, se hizo con antelación-, el presente artículo ha tenido como propósito central ir en busca, en sus múltiples sentidos, de la escritura perdida, al analizar y dar a conocer, por primera vez, algunos de los aspectos más sobresalientes de los manuscritos de El libro vacío. Cion ello, se procuró asentar las primeras bases para el estudio, desde una perspectiva genética, de la escritura de una autora como Josefina Vicens. Es decir, las bases mínimas para la comprensión de la forma en la que realizaba su trabajo literario; ese "camino" que acaso quepa concebir como un método. Un trabajo, tal y como ella lo califica, extraordinariamente arduo y bello, pero que, de manera irónica, contradice - o mejor: contra-escribe - , casi a cada grafía, la imposibilidad y el drama de la escritura de su entrañable José García.

\section{Bibliografía}

Amigo Pino, Claudia y Roberto Zular

Escrever sobre escrever: uma introdução crítica à crítica genética. São Paulo: WMF Martins Fontes, 2007.

Deleuze, Gilles y Félix Guattari

"Percepto, afecto y concepto", en ¿Qué es filosofia? Barcelona: Anagrama, 2001, 163-201. 


\section{Los manuscritos de El libro vacío de Josefina Vicens}

GonzÁlez DueÑas, Daniel y Alejandro Toledo

Fosefina Vicens: la inminencia de la primera palabra. México: Universidad del Claustro de Sor Juana/Ediciones Sin Nombre, 2009.

Granados Salinas, Tomás

Libros. México: Secretaría de Cultura, 2017 (Colección Historia Ilustrada de México, coordinada por Enrique Florescano).

IBARRA, Jesús

Los Bracho: tres generaciones de cine mexicano. México: Universidad Nacional Autónoma de México, 2006.

LÉVINAS, Emmanuel

Fuera del sujeto. Traducción de Roberto Ranz Torrejón y Cristina Jarillot Rodal. Madrid: Caparrós, 2002 (Esprit: 27).

Ortega y Gasset, José

La deshumanización del arte e ideas sobre la novela. Velázquez. Goya. México: Porrúa, 1986.

Pettersson, Aline

"Las pasiones de Josefina Vicens", en Maricruz Castro y Aline Pettersson (editoras). Fosefina Vicens. Un vacío siempre lleno. México: Fondo Nacional para la Cultura y las Artes/Instituto Tecnológico y de Estudios Superiores de Monterrey, 2006, 21-28.

Proust, Marcel

Días de lectura. Traducción de Alicia Matorell y Núria Petit Fontseré. México: Taurus, 2012.

VICENS, Josefina

El libro vacio. Los años falsos. México: Fondo de Cultura Económica, 2011.

The Empty Book: A Novel. Translated by David Lauer. Austin: University of Texas Press, 1992.

VilLoro, Juan

De eso se trata. Ensayos literarios. Barcelona: Anagrama, 2017 (Argumentos: 382).

VITAL, Alberto

"El libro vacio de Josefina Vicens", en Ana Rosa Domenella y Norma Lojero (coordinadoras). Fosefina Vicens: Un clásico por descubrir. México: Universidad Autónoma Metropolitana, 2017, 105-114. 